\title{
熱可塑性ポリイミドを用いた高温用耐放射線性 同軸ケーブルの電気および機械特性
}

\begin{tabular}{|c|c|c|c|}
\hline 瀬口忠男 & (日本原子力研究所) & 非会貝 八木敏明 & (日本原子小破笲淤) \\
\hline 正具 & (株式会社 東 芝) & 非会員 & （株式会社 \\
\hline 男 & （昭和電線電䌫株式会社） & 非会員 & （昭和電線電䌊株式会社） \\
\hline 非会员 & （炤和䨓線需繶林式会社） & 小野真一 & 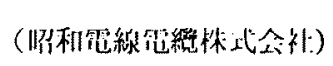 \\
\hline & （昭和電線電纜株式会社） & & \\
\hline
\end{tabular}

Electrical and Mechanical Properties of Coaxial Cable for Use under High Temperature and Radioactive Conditions

Tadao Seguchi and Toshiaki Yagi (Japan Atomic Energy Research Institute), Hisayasu Mitsui and Hiroshi Masumoto (Toshiba Corp.), Takeo Shiono, Masataka Ushiki, Hiroshi Nakamura, Shinichi Ono, and Tohsci Chou (Showa Electric Wire and Cable Co.,Ltd.)

\begin{abstract}
We examined the effect of $\gamma$ - ray irradiation at different temperatures (room temperature and $250{ }^{\circ} \mathrm{C}$ ) and atmospheric conditions ( air and $\mathrm{N}_{2}$ ) on the electrical and mechanical characteristics of thermoplastic polyimide (TPI) insulated and sheathed coaxial cable which is designed for high temperature and radioactive usc. It was found that the TPI insulated and sheathed coaxial cable had good radiation resistance at $250^{\circ} \mathrm{C}$ under $\mathrm{N} 2, \gamma$ -ray irradiation of 75 MGy under air, and electron beam irradiation of about $100 \mathrm{MGy}$ under He. It was also found that both the crosslinking and the crystallization of TPI was accelerated by the syncrgistic effect of heat and $\gamma$-ray irradiation.
\end{abstract}

キーワード：熱可塑性ポリイミド、ク線、電子線、同軸ケーブル、耐熱性

\section{1.はじめに}

耐熱性・耐放射線性に優れている樹脂としてポリイミ ド（P I ）が知られているが、従来のP I は押出被覆が できないため電線への適用はワニスまたはテープ巻きに よる方法しかなかった。

近年、表 1 に示すような特性を持つ熱可䁃性ポリイミ ド（TPI）が開発されたことにより厚肉の絶縁体形成 が可能となり、広い用途に向けた電線の開発が進められ ている。

我々はT P I を絶縁体市よび外被に用いた同軸ケーブ ル（TPIケーブル）について、1.2MGyの 7 線を照 射し2 $20{ }^{\circ} \mathrm{C} \cdot 6$ ヶ月熱劣化 (以下逐次劣化亡称する) を行ったケーブルの電気・機械特性について報告した。 (1),(2)

本報では、T PIケーブルについて熱劣化と放射線照 射劣化およびそれらの複合出化を種々の条件で与え、高 温と放射線環境における耐久性を評価したので報告する。

\section{2.試料ケーブル}

試料ケーブルは第1 報 ${ }^{(1)}$ と同樣に図1に示すような同軸 ケーブル棈造である。絶縁体および外被にTP I（三井

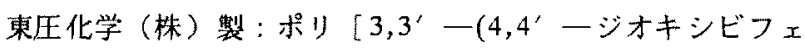
ニル)ジフニレンピロメリットイミド]のホモポリマー) を、内部導体および外部導体に銀めっき軟銅線を使用し た。絶縁厚は試料ケーブルが周辺機器と整合性をとるた め、室温付近での特性インピーダンスが $50 \Omega$ よなるよ うに設定した。表1にTP I の物性值を、表 2 にヶーブ ル構造および室温で測定した初期サンプル（オリジナル） の電気特性を示す。

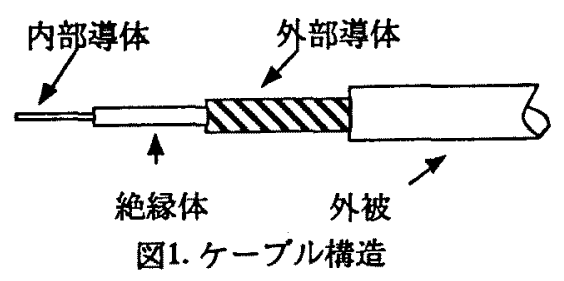




\section{3.劣化条件}

TP I ケーブルの熱および放射線による少化は表 3 に 示す方法で行った。熱劣化（劣化 1) は恒温槽を用い、 窒素ガス霖囲気で行った。放射線劣化は $\gamma$ 線亡電子線照 射で行った。 $\gamma$ 線照射は $\mathrm{Co}^{60} \gamma$ 線による約 $30^{\circ} \mathrm{C}$ 空気中 照射 (劣化 2 ) と高温照射容器 ${ }^{(4)}$ を用いた $250^{\circ} \mathrm{C}$ 、等菜 雾囲気下（劣化 3 ）で行った。電子楾照射（劣化 4) は 密封電子線照射容器 ${ }^{(5)}$ を用い、ヘリウムガス中で試料を 冷却して行った。しかし、電子線加熱により試料温度は 最大 $100^{\circ} \mathrm{C}$ 程度まで上昇していた。

\section{4 .結果}

\section{1 電気特性}

オリジナルおよび劣化 3 のサンプル（250 $0^{\circ} \mathrm{C}$ 窒素 中で $5 \mathrm{MGy}$ の $\gamma$ 線を同洔照射劣化させたもの、以下、5 $\gamma$-T-aged亡略す）について電気特性の比較を行った。

絶縁抵抗亡温度の関係を図 2 に示す。オリジナル、5 $\gamma$-T-agedと屯に絶縁抵抗は高温になるにつれ低下するが、 ガラス転移温度（ $\mathrm{Tg}$ ) より高温になると低下倾问が增

表 1. TPI の物性 ${ }^{(3)}$

\begin{tabular}{|c|c|}
\hline 項 目 & T P I \\
\hline 融点 $\left({ }^{\circ} \mathrm{C}\right)$ & 388 \\
\hline ガラス軽移点 ( $\left.{ }^{\circ} \mathrm{C}\right)$ & 250 \\
\hline 密度 $\left(\mathrm{g} / \mathrm{cm}^{3}\right)$ & 1.33 \\
\hline 比誘電率 (at $1 \mathrm{kHz}$ ) & 3.2 \\
\hline
\end{tabular}

表2. ケープル樓造および室温における軍気特性

\begin{tabular}{|c|c|c|c|}
\hline \multicolumn{3}{|c|}{ 項 目 } & T P I ケーブル \\
\hline \multirow{5}{*}{$\begin{array}{l}\text { 粠 } \\
\text { 造 }\end{array}$} & 内部暚体 & 搆成 & 銀めっき软銅線 1 本 $/ 0.26 \mathrm{~mm}$ \\
\hline & 絶縁体 & 厚さ $(\mathrm{mm})$ & 約 0.4 \\
\hline & 外部導体 & 椣威 & 銀めっき軟銅線 横巻シールド \\
\hline & 外被 & 厚さ $(\mathrm{mm})$ & 約 0.2 \\
\hline & \multicolumn{2}{|c|}{ 外径 (mm) } & 䄪 1.7 \\
\hline \multirow{4}{*}{$\begin{array}{l}\text { 電 } \\
\text { 気 } \\
\text { 特 } \\
\text { 性 }\end{array}$} & \multicolumn{2}{|c|}{ 特性インピーダンス ( $\Omega$ at $10 \mathrm{MHz})$} & 50.4 \\
\hline & \multicolumn{2}{|c|}{ 絶縁抵抗 (MSkm) } & $1.2 \times 10^{6}$ \\
\hline & \multicolumn{2}{|c|}{ 減衰量 ( $\mathrm{dB} / \mathrm{km}$ at $10 \mathrm{MHz})$} & 124.0 \\
\hline & \multicolumn{2}{|c|}{ 䋫電容量（ $\mathrm{nF} / \mathrm{km}$ at $1 \mathrm{kHz}$ ) } & 120.5 \\
\hline
\end{tabular}

表了热および故射劣化の策件

\begin{tabular}{|c|c|c|c|c|c|}
\hline 㸓化条件 & 放射線 & $\begin{array}{l}\text { 線吾事 } \\
(\mathrm{k} G \mathrm{y} / \mathrm{h})\end{array}$ & 㞣团気 & $\begin{array}{l}\text { 温度 } \\
\left({ }^{\circ} \mathrm{C}\right)\end{array}$ & 借 \\
\hline 劣化 1 & - & - & $\mathrm{N}_{2}$ 、大気政 & 250 & 熱劣化 \\
\hline 劣化 2 & $\gamma$ 線 & 20 & Air、大気压 & $\sim 30$ & $\gamma$ 線、 100MGy \\
\hline 出化 3 & $\gamma$ 線 & 20 & $\mathrm{~N}_{2}$ 、大気政 & 250 & 熱 $\cdot \gamma$ 楾䔮合、 10MGy \\
\hline 秀化 4 & 㧘子線 & $\begin{array}{c}2 \times 10^{4} \\
(5.6 \mathrm{kGy} / \mathrm{s})\end{array}$ & He、大受正 & $\sim 100$ & 電子線、 $95 \mathrm{MGy}$ \\
\hline
\end{tabular}

している。これは逐次劣化の試料も同一傾向であった ${ }^{(1)}$ 。 次に減衰量之温度の関係を図 3 に示す。オリジナル、 $5 \gamma$-T-agedともに $250^{\circ} \mathrm{C}$ 付近までの温度上昇では著し い減衰量の增加は観測されず、逐次少化の試料と同一傾 向であった ${ }^{(1)}$ 。

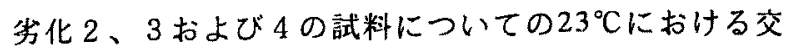
流絶縁破壊電圧（B D V) を表 4 に示す。表 4 より、少 化後でも B D Vの低下は比較的少ないと言える。

\section{2 機械特性}

少化 1 および少化 3 のサンプルについて、2 $50{ }^{\circ} \mathrm{C} に$ おける引張強さの测定を行った。引张強さと熱劣化時間

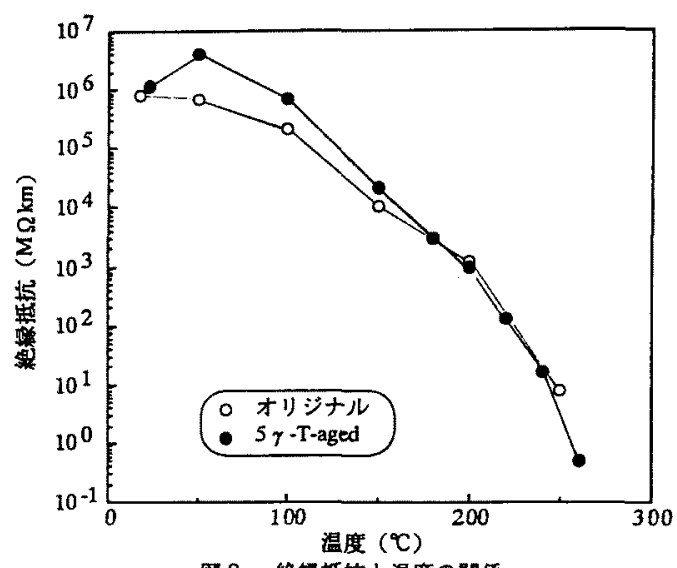

图 2、絶䜌抵抗と温度の関係

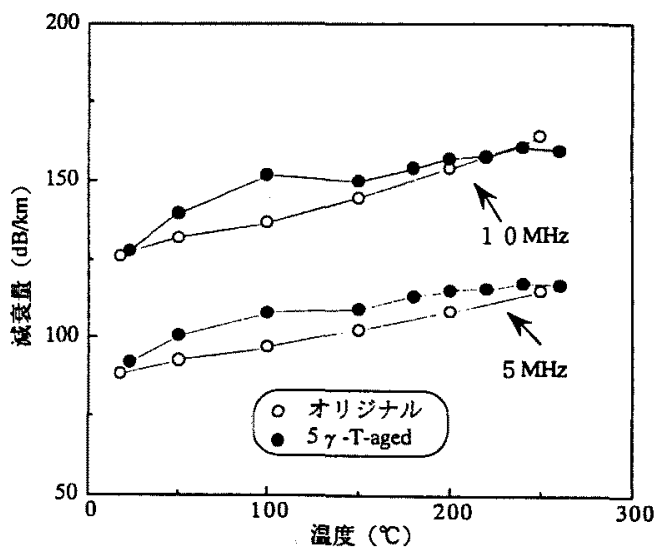

因 3. 減衰是と温度の関係

表4. 分化後の絶緑破脿特性

\begin{tabular}{|c|c|c|c|c|c|c|c|c|c|}
\hline サンプル & オリジナル & $\begin{array}{c}\text { 尔化.1 } \\
\text { (热) }\end{array}$ & $\begin{array}{l}\text { 少化 } 2 \\
(\gamma \text { 線) }\end{array}$ & \multicolumn{4}{|c|}{$\begin{array}{l}\text { 少化 } 3 \\
(\gamma \text { 線) }\end{array}$} & \multicolumn{2}{|c|}{$\begin{array}{c}\text { 务化4 } \\
\text { (電子缐) }\end{array}$} \\
\hline $\begin{array}{l}\text { 照射覃 } \\
\text { (MGy) }\end{array}$ & 0 & $\begin{array}{c}0 \\
(250 \times \\
500 \mathrm{hr})\end{array}$ & 100 & 1 & 3 & 5 & 10 & 60 & 95 \\
\hline $\begin{array}{c}\text { B D V } \\
\text { (kVms) }\end{array}$ & 32.9 & 26.2 & 25.7 & 23.1 & 20.4 & 23.6 & 21.8 & 27.2 & 23.6 \\
\hline
\end{tabular}

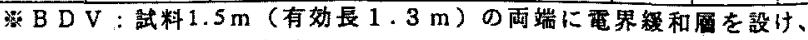
200 ○気中て、昇压速度 $0.5 \mathrm{kV} / \mathrm{s}$ で娜定。 
の関係を図 4 に示す。劣化 1 のサンプルは、熱劣化時間 が長くなるにつれ強度が徐々に低下する傾向がみられた。 一方、劣化 3 のサンプルについては熱劣化時間が $50 \mathrm{~h}$ 以上では著しく低下していることがわかる。なお、我化 3の10 MGy照射したサンプルについては出化の度合い が大きく、測定不可能であった。劣化 2 および劣化 4 に ついては、図5に示すように、試験終了後においても才 リジナルと同等レベルの引張強さを有していた。

また、各劣化条件のサンプルについて可之う性の評価 は、室温においてサンプルの自己径に 10 回巻き付けて クラック発生の有無を目視で観察する自己径巻き付け試 験（UL規格７58 FLEXIBILITY TEST準拠）で行っ た。その結果を表 5 に示す。劣化 1 、劣化 2 、劣化 4 と もにサンプルのクラック発生（外被、絶縁体とも）はみ られなかったが、劣化 3 の場合のみ、10 MGy照射した サンプルにクラックが発生（外被のみ。絶縁体はクラッ

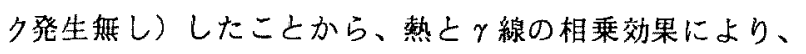
劣化を促進していることがわかる。ただし、絶縁体にク ラック発生は見られなかったので、電気特性（BDV） に対する影響はなかった。

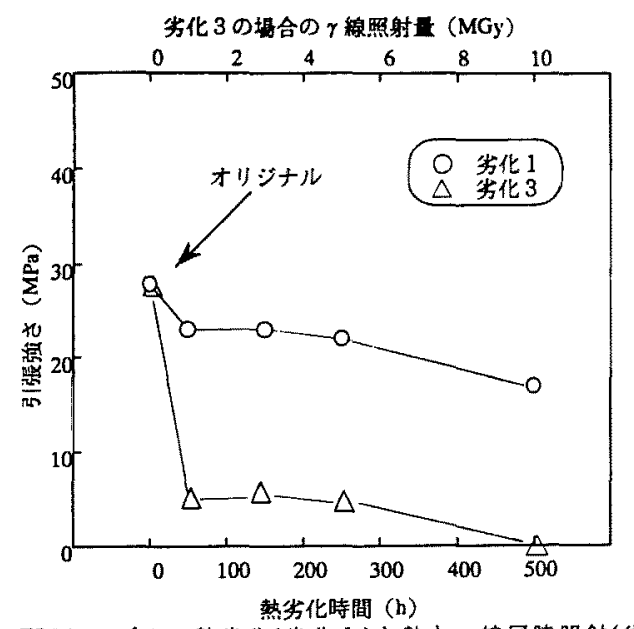

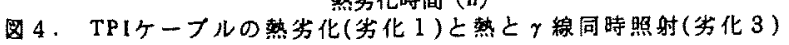
した時の引張强さ $\left(250^{\circ} \mathrm{C} て ゙\right)$ と劣化時間の関係

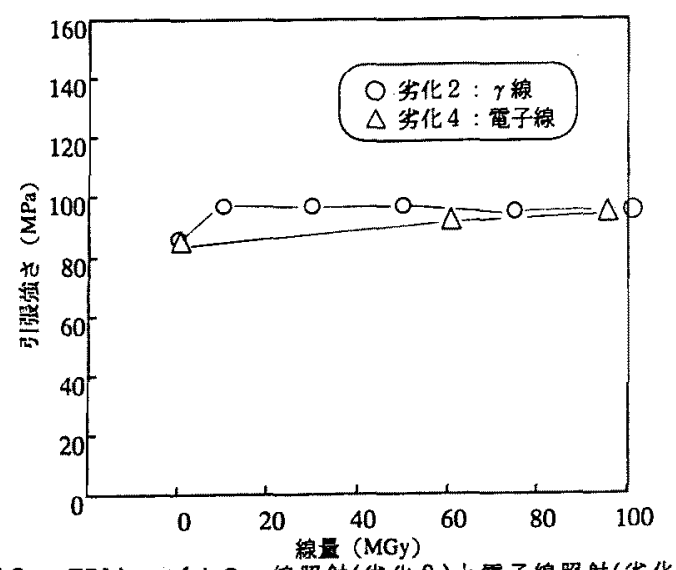

因 5、TPIケーブルのケ線照射(劣化 2)と電子線照射(劣化 4) した時の引倨強さ $\left(23^{\circ} \mathrm{C}\right)$ と線姐の的係

\subsection{S C 測定による熱特性 (6)}

T P I ケーブルへの加熱、 $\gamma$ 線照射による影響を確認 するために示搳走查熱最（DＳＣ）分析を行った。DS Cはケーブルの外被材料を裁断したものを朋い、10 10 / minの昇温速度で測定した。T PIケーブルの加熱によ る影暗（劣化 1 ）についてのDSCスペクトルを図 6 に 示す。TPIのオリシナル妵 $250^{\circ} \mathrm{C}$ 付近にT gに起因 する変曲点、 $300^{\circ} \mathrm{C}$ 付近に発熱ピーク ( T C )、およ び、38 $8^{\circ} \mathrm{C}$ 付近に結晶融解による吸熱ピークがそれぞ れ観測される。T C は D S C 測定の昇温過程で、結晶化 が生じていることを示している。また、結晶融解による 吸熱量と「cの発熱量の差が熱少化の過程で結唱化が進 んでいることを示している。また、熱出化時間を長くす ると T c は低温侧へシフトし、T c ピークは小さくなっ ている。これは、ガラス転移温度での熱劣化により、結 晶化が起こり、熱劣化時に僅かに結晶化した部分が核と なり、小さなサイズの結晶がより多く生成されるためと 考えられる。

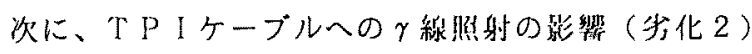
についてのDSCスペクトルを図 7 に示す。Tcは高線 量になるにつれ、高温側へシフトし、そのピークは小さ くなり、30 MGy以上では消隇する。この場合、照射は 約 $30^{\circ} \mathrm{C}$ と低温であり、分子通動は不活発なため非昆啠 部分での架橋や分子鎖の再配列は起きす、また熱分解も 生じない。このようなことを考虑すると、图 7 に示した 現象は、放射線で誘起される酸化反応がT P I の非昆部

表 5。自己䧲卷き付けによるクラックの発生

\begin{tabular}{|c|c|c|c|c|c|c|c|}
\hline \multirow[t]{2}{*}{ 劣化 1} & $250^{\circ} \mathrm{C}$ 加熱時间( $\mathrm{hr}$ ) & $0\left(x+I^{2}+N\right)$ & 50 & 150 & 250 & 500 & $-\cdots$ \\
\hline & クラック & $0 / 10$ & $0 / 10$ & $0 / 10$ & $0 / 10$ & $0 / 10$ & $\longrightarrow$ \\
\hline \multirow[t]{3}{*}{ 劣化 2} & 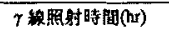 & 60 & 500 & 1500 & 2500 & 3750 & 5000 \\
\hline & 線吾(MGy) & 1.2 & 10 & 30 & 50 & 75 & 100 \\
\hline & クラック & $0 / 10$ & $0 / 10$ & $0 / 10$ & $0 / 10$ & $0 / 10$ & $0 / 10$ \\
\hline \multirow[t]{3}{*}{ 劣化 3} & $250^{\circ} \mathrm{C}$ 加熱时明( & 50 & 150 & 250 & 500 & $+\ldots$ & - \\
\hline & 線帮(MGy) & 1 & 3 & 5 & 10 & - & - \\
\hline & クラッタ & $0 / 10$ & $0 / 10$ & $0 / 10$ & $10 / 10$ & - & - \\
\hline \multirow[t]{3}{*}{ 劣化 4} & 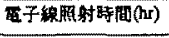 & 3 & 4.75 & - & - & - & - \\
\hline & 綿量(MGy) & 60 & 95 & - & - & - & - \\
\hline & クラック & $0 / 10$ & $0 / 10$ & - & - & - & - \\
\hline
\end{tabular}

※クラックの発生は、クラック発生ターン数/10夕ーンで示した。

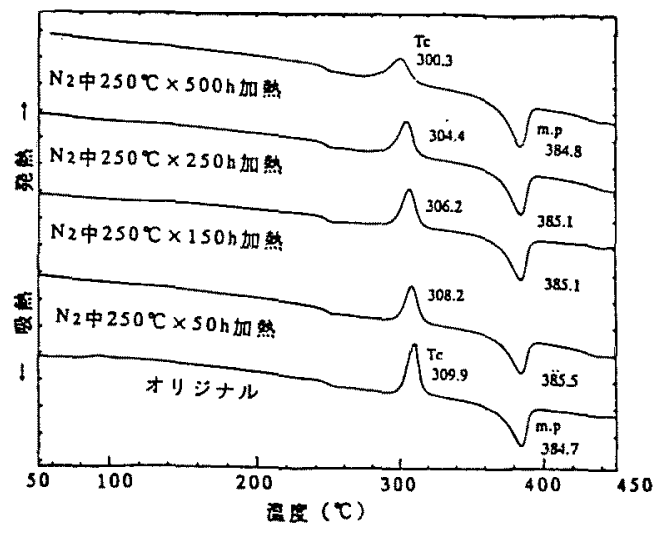

図6.TPIケープルの熱劣化(少化 1) によるD S C 曲線の变化

電学論A，116 巻 2 号, 平成 8 年 
分で起こり、酸化物が生成（一部切断）したため、D S C测定の昇温過程で生ずる結晶化が阻害され、起きたも のであると考えられる。30 M G y 以上おいてTcが 観测されなくなり、また、融解ピークが消失するのは結 晶化の阻害の程度が大きくなったためと考えられる。

T P I ケーブルの熱亡 $\gamma$ 線同時照射の影響（劣化 3) についてのDＳCスペクトルを图 8 に示す。また、図 8 に見られる現象について整理した結果を図 9 に示す。1 MGy以上の線量を同時照射したどのサンプルもオリジナ ルや我化 1、2のサンプルのDSC曲線とは異なり、Tc の発熱ピークはみら扎い。 $\gamma$ 線による架橋は非昆質部 分で起こるが、250 $0^{\circ} \mathrm{C}$ (ガラス転移温度)においては

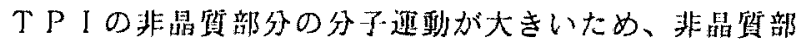
分の架橋が起こる確率が高いと考えられる。架橋が起こ るためD S C 測定の昇温啲程での結晶化が阻害され、3 $00{ }^{\circ} \mathrm{C}$ 付近の結晶化ピークがなくなったものと考えられ る。しかしながら、同特照射中に結晶化も同時に起こっ ているため、結昆の融解ピーク（380 ${ }^{\circ} \mathrm{C}$ 付近）は存在 している。照射量が增加すると融解ピークが小さくなっ ていくことは架橋が進行して、同時照射中での結晶化が 抑制され、結晶サイズが小さくなるためと考えられる。 また、T $\mathrm{x}$ の吸熱は $\gamma$ 線と熱により一部結晶が破壤され たものと考えられる。加熱・ $\gamma$ 線同時照射の時間が增す につれ、 Tgにおける変曲点がなくなっている。これは、 非晶質部分での架橋上分子鎖の再配列が影留しているた めと思われる。

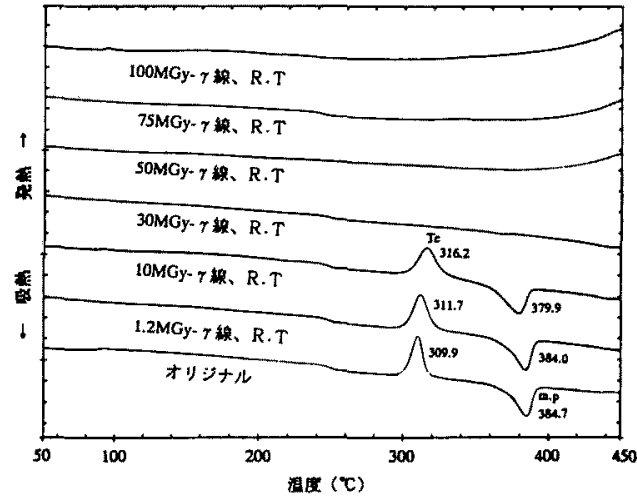

园7.TPIケープルを案榅・大気中 $\gamma$ 緗照射 （劣化 2）した時のDSCスペクトル

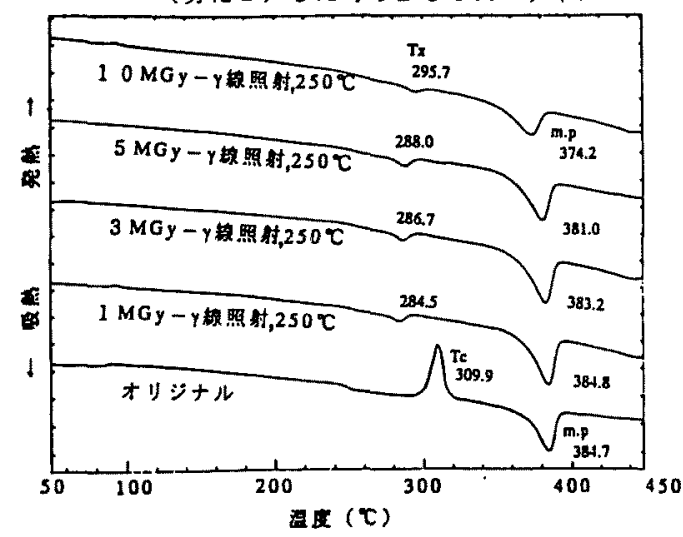

因 8. TPIケーブルの熱 $\left(250^{\circ}\right.$ C $) と \gamma$ 線同時照射 （少化 3）によるDSCスベクトル

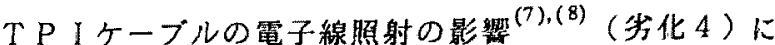
ついて测定を行った結果を図 10 に示す。6 $0 、 95$ MGyともにD S C 曲線においてT g が上昇し、またT の発熱ピーク、融解ピークがみられなかった。これは、 T P I 架橋による変化を示している。

\section{$4.4 \times$ 線回折による結晶化度測定}

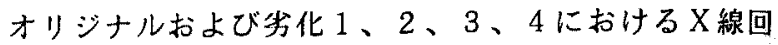
折像を図 11 に示す。オリジナルおよび窒温で $\gamma$ 線を 1 $00 \mathrm{MG} \mathrm{y}$ 照射したもの（100MGy・RT）（少化 2) および麗子楾を95MG y 照射したもの（95 MGy. 電子線）（劣化 4) は少化試験において全く結晶化が認 められない。250 0 Cの窒素中で 500 時間加熱したも の $\left(250{ }^{\circ} \mathrm{C} \cdot 500 \mathrm{~h}\right)$ (少化 1 ) は嚾加に結思化加

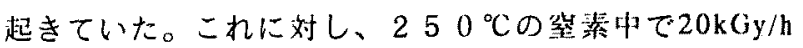
の線量率の $\gamma$ 線を 500 時間同時照射したもの（10MGy : $250{ }^{\circ} \mathrm{C}$ ) (劣化 3 ) は、結晶による反射ピークが鮮明

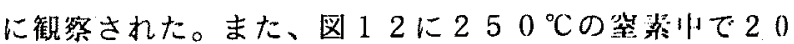
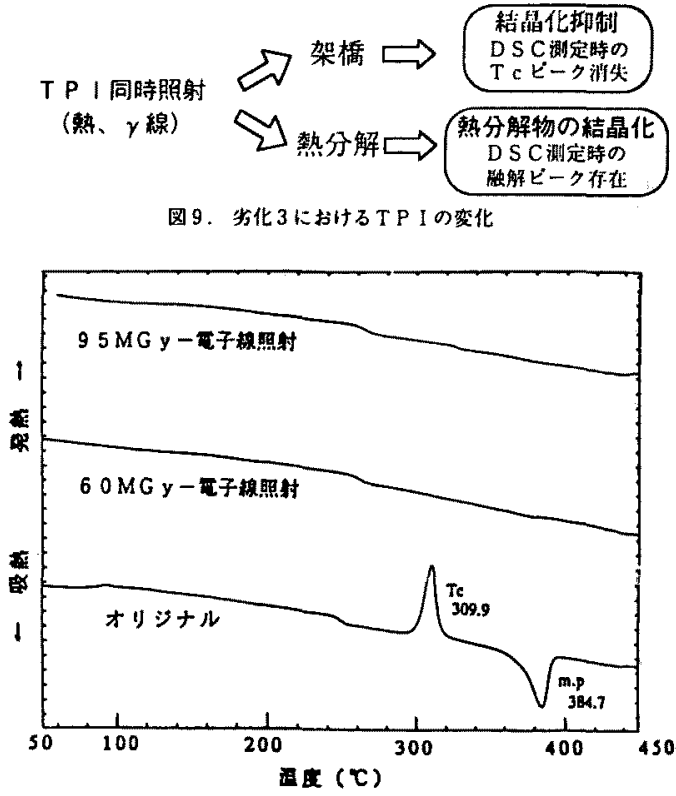

图 10.T P I ケープルの落子線照时（少化 4) によるDSCスペクトル

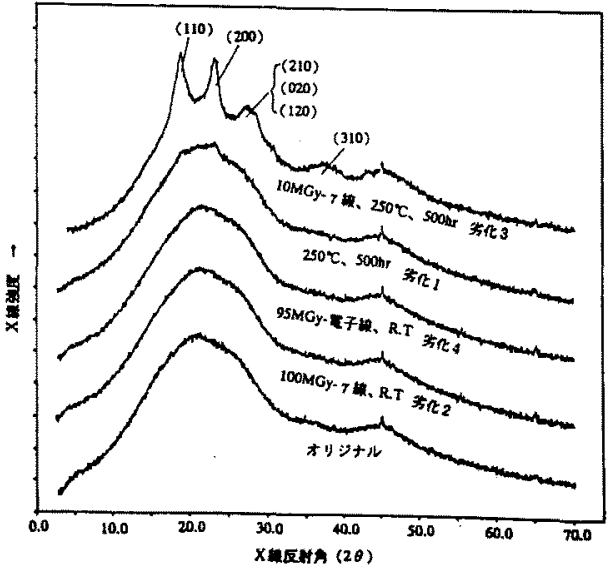

图11.TPIケープルの各劣化条件による $\mathrm{X}$ 線回折倿化 
k G y / h の線量率の $\gamma$ 線を同時照射 (劣化 3 ) による線

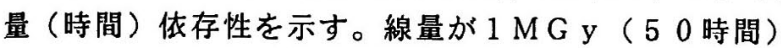

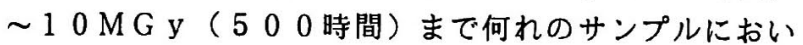
です結晶化度は約 $16 \%$ \%゙った。

図11のX線回析図形における劣化 3 の結晶ピークに ミラー指数 ${ }^{(9)}$ を示した。

ここで、図 11 に示される $250{ }^{\circ} \mathrm{C}$ 窑素中で $20 \mathrm{kGy} / \mathrm{h}$ の線量率の $\gamma$ 線を 500 時間同時照射したもの (劣化 3 ) とN2中 $250{ }^{\circ} \mathrm{C} て ゙ 500 \mathrm{~h}$ 加熱したもの（劣化 1 ）の間 の少化試験中における結晶化度に大きな差がある原因と しては、 $\boldsymbol{\gamma}$ 線照射により熱分解が加速され、低分子量化 した成分が結晶化を起こしているものと考えられる。た だし、劣化 1 においても若千の熱分解が起きており、そ のために図 11 で僅かな結晶化が現れているものと思わ れる。また、図 12 に示される $250^{\circ} \mathrm{C}$ 窒素中で $20 \mathrm{k}$ G y / h の線量率の $\gamma$ 線を照射したもの（劣化 3 ）に、線 量（時間）依存性が認められない原因としては、 $\gamma$ 線照 射量の低い段階（試験閁始後 50 洔閵以内）で热分解に よる結晶化が生ずるものの、放射線の線量を增大すると 架橋密度が上がり、結晶化に寄与する成分がほとんど消 失すると考えられる。

\section{5 .まとめ}

1) T P I を用いた同軸ケーブルは、窒素中・ $250^{\circ} \mathrm{C}$ 熱劣化（劣化 1) において、大きな電気特性、機 械特性の低下はみられず、優れた耐放射線性を有 することが確認できた。

2) 室温における大気中・100 MGyの $\gamma$ 線照射（劣 化 2 ）、およびヘリウム中 $95 \mathrm{MGy}$ の電子線照射 （劣化 4 ）に対しても大きな電気特性、機械特性 の低下は見られず、優れた耐放射線性を有するこ とが確認できた。

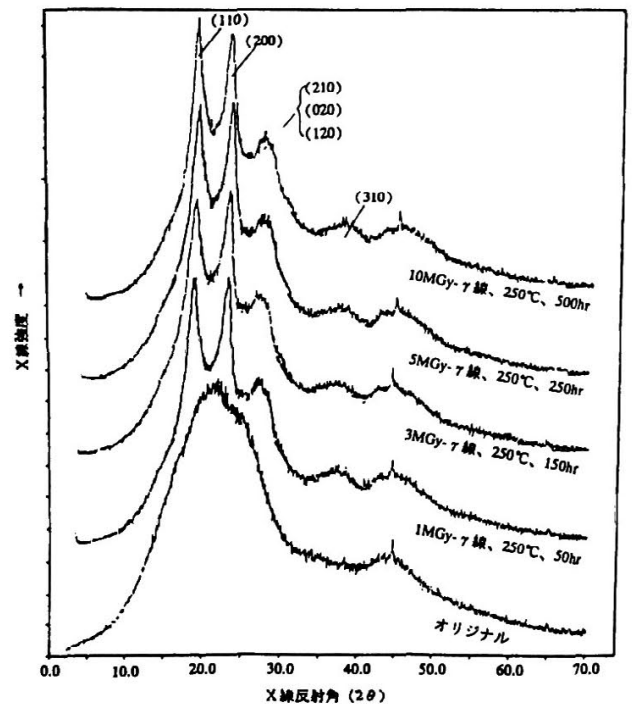

四12.TPIケープルの熱 $\left(250^{\circ} \mathrm{C}\right)$ と 線同時照射 (少化 3 ) によるX線回折像の変化

3 ) 窒素中・2 $50{ }^{\circ} \mathrm{C}$ (ガラス転移点) での加熱下で $\gamma$ 線を同時照射した場合（劣化 3 ）、大きな電気 特性の変化はみられなかった。機械特性は照射量 が增大するに従い、著しい低下がみられた。この 機械特性の低下は、T P I の熱劣化が $\gamma$ 線により 加速されたためと考えられる。

4) 加熱下における $\gamma$ 線同時照射においては、照射時 における結晶化が促進されることが判明した。こ れは $\gamma$ 線照射により窒素中における熱分解が加速 され、熱分解物が結晶化するためと推定される。

(平成 7 年 5 月 1 日受付、同 7 年 7 月 28 日再受付)

\section{参考文献}

（1）三井、塩野他, “熱可塑性ポリイミドを用いた高 温用耐放射線同 軸ヶーブルの電気および機械特性”； 電学論 $A, 115$ 巻4号, 338 343(1995).

( 2 ) H.Mitsui, T.Shiono et al, "Electrical propertics of Thermoplastic Polyimide Insulated Coaxial Cable for Use at High Temperature and Under Radioactive Condition", International Wire \& Cable Symposium Proceedings P700(1994).

（３）江崎, “熱可塑性ポリイミド「A U R UM」1”, バルカレビュー,37（7）,1〜6（1993）。

（4）八木敏明、森田洋右、瀬口忠男，「核融合炉(ITER) 用鼓隔保守機器・部品照射試験装置の設計と製作」, JAERI-Tech, 95-015 (1995).

（5）金沢孝夫、春山保幸、四本圭一,「電子線照射容器 の製作とその特性」,JAERI-M,92-062（1992）。

(6) T.H.Hou et al, "Characterization of Thermoplastic Polyimide New TPI", SAMPE Quarterly, 33 $\sim 46(1991)$.

( 7 ）平出他, "全芳香族ポリイミドの電子線照利效果 ", 電気学会絶縁材料研究会資EIM-88-132(1988).

( 8 ) T.Hirade et al , "Radiation effect of aromatic thermoplastic polyimide (NEW-TPI)" Polymer, 32,14 (1991).

(9) K.Okuyama et al, "X-ray Structure Analysis of Thermoplastic Polyimide", Macromolecules, P 7261 (1992).

瀬口忠男

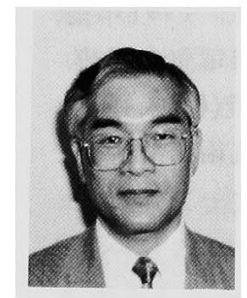

（正員）1941年10月20日生。1966年北海 道大学大学院工学研究科修上課程修了。 同年、日本原子力研究所入所。現在、同 所高崎研究所材料開発部次長兼極限材料 研究室長。工学博士。主として、有機材 料の耐放射線評価と耐放射線材料の研究・ 開発に従事。高分子学会、原子力学会会 員。 


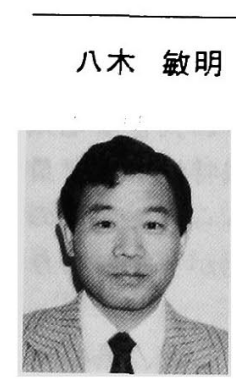

三井久安

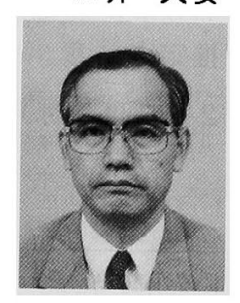

增本 博

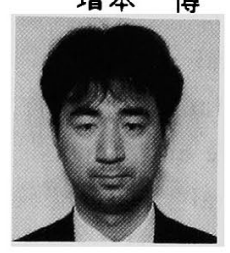

塩野 武男

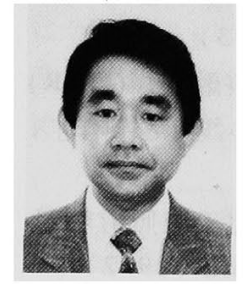

牛木 雅隆

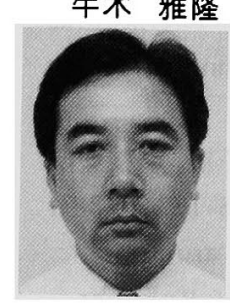

中村 宏

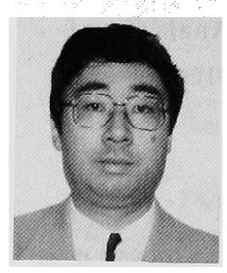

小野 真一

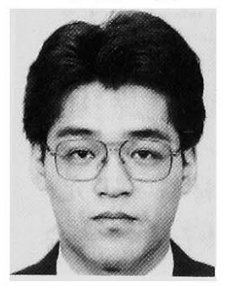

（非会員）1950年4月19日生。1973年群 馬大学工業短期大学工業化学科卒業。 1969年日本原子力研究所入所。現在、同 所高崎矿究㪼材料關発部主查。主として、 原子炉用電楾の寿命評価の技術開発に従 事。1991 年科学技術庁創意工夫賞受賞。 高分子学会、放射線化学会会員。

（正員）1942年9月7日生。1965年名古屋 工業大学工業化学科卒業。同年 (株) 東 芝入社。現在、同社重電技術研究所主幹。 主として、絶縁システムの研究・開発に 従事。工学博士。I E E E S M. 技術士。 1973 年日本電気工業会発達賞、1987年日 本非破壊検查協会奖励賞受賞。

（非会員）1966年1月22日生。1991年名 古屋工業大学大学院工学研究科電気情報 工学専攻修了。同年 (株) 東芝入社。現 在、同社核融合開発部技術主任。主とし て、核融合灯棈造、遠隔機器開発に従事。

（会員）1950年7月19日生。1979年東京 大学大学院博士課程修了。工学博士。同 年炤和電線電䌫 (株) 入社。現在、情報 通信研究部材料研究室室長。主として、 光・通信ケーブル用材料の研究・開発に 従事。高分子学会、応用物理学会会員。

（非会員）1954年7月10日生。1977年電 気通信大学電気通信学部通信工学科卒業。 同年昭和電線電繶（株）入社。現在、光 · 通信技術部通信技術第 2 課課長。主とし て、通信ケーブル及び移動体通信システ ムの研究・開発に従事。

（非会員）1960年3月1日生。1983年静岡 大学工学部工業化学科卒業。同年昭和電 線電纜 (株) 入社。現在、情報通信研究 部材料研究室勤務。主として、光・通信 ケーブル用材料の研究・開発に従事。電 子情報通信学会会員。

（非会員）1964年10月14日生。1991年室 蘭工業大学大学院工学研究科電気工学専 攻修了。1992年昭和電線電繇(株)入社。 現在、光 - 通信技術部通信技術第 2 課勤 務。主として、信号伝送用ヶーブルの研 染・開発に従事。

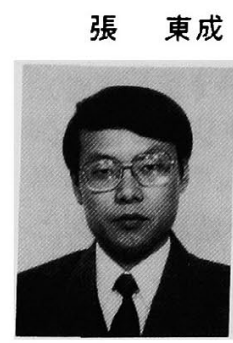

（非会員）1964年1月6日生。1993年埼玉 大学大学院理工学研究科化学夺攻修了。 同年昭和電線電䌫（株）入社。現在、情

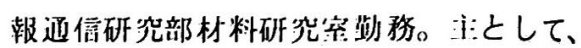
光・通信ケーブル用材料の研究開発に従 事。 